\title{
Ex-situ population of White-rumped Shama (Copsychus malabaricus): Studies of density, distribution and bird keepers in Bengkulu, Sumatra
}

\author{
HERI DWI PUTRANTO ${ }^{1,2, \boldsymbol{v}}$, BIENG BRATA ${ }^{1,2}$, YOSSIE YUMIATI ${ }^{3}$ \\ ${ }^{1}$ Department of Animal Science, Faculty of Agriculture, Universitas Bengkulu. Jl. W.R. Supratman, Kandang Limun, Bengkulu 38371, Indonesia. \\ Tel.: +62-736-21170, Fax.: +62-22105, •email: heri_dp@unib.ac.id \\ ${ }^{2}$ Graduate School of Natural Resources Management, Faculty of Agriculture, Universitas Bengkulu. Jl. W.R. Supratman, Kandang Limun, \\ Bengkulu 38371, Indonesia \\ ${ }^{3}$ Program of Agribusiness, Faculty of Agriculture, Universitas Dehasen Bengkulu. Jl. Raya Meranti, Sawah Lebar, Bengkulu 38227, Indonesia
}

Manuscript received: 26 November 2019. Revision accepted: 3 February 2020.

\begin{abstract}
Putranto HD, Brata B, Yumiati Y. 2020. Ex-situ population of White-rumped Shama (Copsychus malabaricus): Studies of density, distribution and bird keepers in Bengkulu, Sumatra. Biodiversitas 21: 865-874. Purpose of this research was to estimate number of White-rumped Shama (Copsychus malabaricus) or locally known as murai batu which are kept by Bengkulu's bird keepers, analyze its population density, population distribution, and the profile of bird keepers. Researcher used field observation method by conducting interviews during June-September 2019. Respondents were determined using purposive sampling method and sampling was continued by snowball sampling method. Bird population data were analyzed by using population density formula and population distribution formula, while profile of bird keepers was analyzed descriptively. In 9 sub-districts of Bengkulu City total of 642 birds that are kept by bird keepers in ex-situ habitat, consisting of 434 males and 208 females with sex ratio approximately of 2:1. Population density was 4.23 birds per $\mathrm{km}^{2}\left(2.86\right.$ male birds $/ \mathrm{km}^{2}$ and 1.37 female birds $/ \mathrm{km}^{2}$ ). Population distribution by a Variance-Mean Ratio formula was 4.8 or VMR > 1. Furthermore, there were 79 keepers consist of 78 male bird keepers (98.7\%) and 1 female keeper (1.27\%). Eleven bird keepers $(13.9 \%)$ were categorized as captive breeders and 68 keepers $(86.1 \%)$ were categorized as bird hobbyists. In conclusion, density population of ex-situ White-rumped Shama in Bengkulu City was 4.23 birds per $\mathrm{km}^{2}$, and population distribution interpreted as negative binomial distribution. Bird keepers were divided into two groups, captive breeders and bird hobbyists.
\end{abstract}

Keywords: Bird fanciers, Bengkulu, Sumatra, murai batu, number of birds

\section{INTRODUCTION}

Among 204 countries located on 5 continents in the world, Indonesia floral and faunal biodiversity is highly recognized and it was a basis for a scientific designation of Indonesia as a world's mega biodiversity. One of Indonesia's faunal natural resources is the endemic bird species which is very easy to receive disturbance regarding biological, ecological and physical problems. At present, several species of birds are experiencing a decline in population due to cases of illegal poaching to meet a highly demand bird keepers to own them. For example, there had been a case of a population decline of Bali starlings that inhabited the island of Bali as their in situ habitat a few decades ago.

Alves et al. (2013), van Balen et al. (2013) and Shepherd et al. (2013) wrote that trading activity of wildlife species is known to be driving decline of a limited number of species in all major vertebrate in the regions such as Asia, South America, and Africa. Eaton et al. (2015) reported that 13 species of Indonesia birds were strongly assumed as nearly extinct in their in situ habitat caused by trading activities. Even though the real number of Indonesia market demand for bird trading is still unclear (Harris et al. 2015), we presumed bird keepers or for Indonesians usually called also as bird lovers also contribute to become a factor for a declining of bird population in the wild, especially for illegal trading. It is supported by reports of Nijman (2010) and Duckworth et al. (2012), the consequence of commercial trade on animal populations in Asia region was animals being pushed towards extinction, including local birds. Added by Eaton et al. (2015), one of bird species which is White-rumped Shama (Copsychus malabaricus) or murai batu probably already extinct in the wild, due primarily to trade.

CABI.org (2020) wrote that White-rumped Shama bird would be easily recognizable by its long black tail with white outer feathers, also by its chestnut belly and the white patch on its lower back. Usually, females are distinctly smaller than males and more brownish rather than black. Furthermore, it is well recognized that young White-rumped Shama birds have shorter tails and the brownish coloration of females (with scalloped plumage on the breast). Male birds average $27 \mathrm{~cm}$ in length with a tail of about $18 \mathrm{~cm}$ long, while female birds average $22 \mathrm{~cm}$ in length with a tail of approximately $14.5 \mathrm{~cm}$ (Low 2006). Based on BirdLife International (2015) report, $C$. malabaricus has a large range extending from northern India, Nepal, and southern China to Sri Lanka and Indonesia. Number of this species is suspected to be in decline owing to ongoing habitat destruction and the pet trade (Collar 2005). Shepherd et al. (2004) reported that cage-bird traders in Sumatra claimed that it had vanished from many areas throughout the island. It has been 
introduced to Hawaii (Pyle and Pyle 2009) and Taiwan (Fan et al. 2009).

There are reasons for bird keepers to keep bird as their pets such as price, morphological color, and forms. However, the quality of a bird's song is also most important factor for bird keepers to determine their decision. Lee et al. (2016) reported that the Asian Songbird Trade Working Group launched the "Conservation Strategy for Southeast Asian songbirds in trade (Recommendations from the first Asian Songbird Trade Crisis Summit 2015 held in Jurong Bird Park, Singapore, 27-29 September 2015)". This strategy, which lists species of high priority in urgent need of conservation action. Among the actions outlined for the species is the establishment of total legal protection in Indonesia. According to Irawati et al. (2016), among local Indonesians, there are several reasons such as the beauty of the color and feathers pattern, the unique and exotic morphological forms, the degree of scarcity, and the specialties or abilities of certain types of birds (such as for imitating sound, acrobatic movement, or communication skill) have made birds became a favorite choices for humans to be owned.

According to Iskandar (2016), habit of keeping birds has long been known in Indonesian society and even traditionally in some culture, this habit is still preserved. There are several purposes of keeping birds done by bird keepers. Hobbies, economic values, conservation and cultivation, scientific studies, even a prestige or a high ranking level in a certain social status (Irawati et al. 2016). The results of a study by Amama and Triwiduri (2007) shown that among societies who lived in Java and Bali island, birds became favorite pets $(35 \%)$ and this number was higher than fish and kitten numbers. Jepson (2010) had conducted field research in Java and Bali island, and found that 1 in 3 respondent families kept birds and 2 in 3 respondent families kept birds as pet in last ten years. Furthermore, the study results conducted by Rosyadi et al. (2015) shown that in several metropolitan cities in Indonesia, there was about $21.8 \%$ of respondent families kept birds as pets. In the past decade, the prestige of Whiterumped Shama ( $C$. malabaricus) as a domestic pet in Indonesia, individuals for sale were especially in Bengkulu, has increasingly accelerated (Putranto et al. 2018, 2019). This report is also supported by Iqbal et al (2015), Whiterumped Shama bird is widely known as one of 10 species most frequently posted with the highest number in online trading in South Sumatra. Main reason for this situation is because of the price of an expensive White-rumped Shama, especially if the bird has become a champion in a birdsong competition which is frequently conducted by local bird lovers community in Bengkulu City.

Copsychus malabaricus is classified as a chirping bird that is considered intelligent (Figure 1). Mu'arif (2012) said that this bird's fame not only based on its singing voices, however male birds fighting style is also very attractive. This is supported by a scientific fact that White-rumped Shama is a member of family Turdidae. According to Putranto et al. (2018), the family Turdidae bird is known to have a good singing ability with a melodious voice and very varied. White-rumped Shama is a babble bird type that is frequently being competed in a birdsong contest. It became a bird species who has its own prestige among chirping bird lovers. Furthermore, this species has a fairly high level of intelligence compared to other bird species. It is shown by its ability to record, remember, and then mimic other bird sounds or sounds of objects around it become their own song (Brata et al. 2019). In addition, this bird can sing and produce a melodious voice, loud, has a variety of songs that sound unbroken, and sang by one breath. This bird is recognized as a relatively shy bird (Saputro et al. 2016), furthermore, White-rumped Shama is well known as a bird which relatively adaptable, easily tamed, and not easily stressed as long as adequate care is given. Contrary to these scientific facts, based on local bird keepers experiences in Bengkulu City they found White-rumped Shama is an easily stressed species especially during day-0 until day-90 after hatched (chicks). Chicks are required specific treatments such as rearing technique (feeding method, feeding frequency, type of feeding food) and wellcontrolled environment which can provide a comfortable situation for chicks to grow. A feeding error or noisy environment can easily affect chick health and surviving, later those factors can lead to high mortality.

Based on preliminary survey results that have been carried out by the research team earlier, it was found that there were 4 White-rumped Shama types in Bengkulu locally including known as North Bengkulu White-rumped Shama, South Bengkulu White-rumped Shama, Medan White-rumped Shama, and Aceh White-rumped Shama. There is no written scientific evidence or data to identify those birds. We assumed that birds naming is adjusted to origin of the area where birds are obtained or purchased. Furthermore, some scientific study results on Whiterumped Shama discussed about behavior (Saputro et al. 2016), feasibility studies of breeding business (Sujana 2016), reproductive studies (Putranto et al. 2018), hatching machines (Fahruzi and Suryowinoto 2019), daily management (Brata et al. 2019) and bird keeper population studies (Putranto et al. 2019).

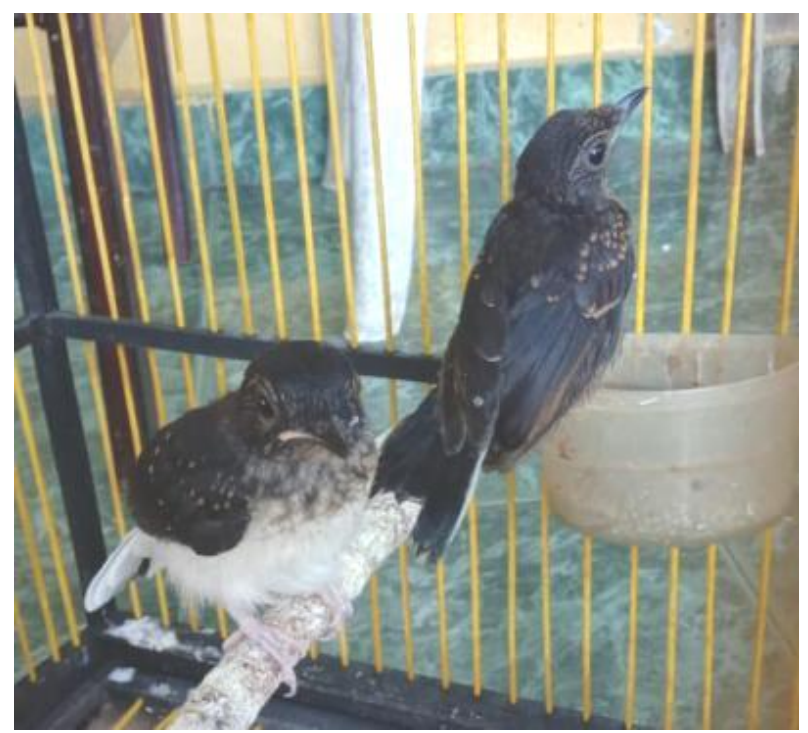

Figure 1. Two White-rumped Shama (Copsychus malabaricus) birds in ex-situ kept by bird keeper in Bengkulu City 
As a conservationist, we still have no data regarding the population and origin of White-rumped Shama which are kept by bird keepers in Bengkulu City. It is still unknown with certainty. As we have mentioned earlier, some reports said capturing White-rumped Shama from its in situ habitat when it is not accompanied by an appropriate surveillance and preservation program, it can be lead to population decline and scarcity in nature (Eaton et al. 2015; Duckworth et al. 2012; Nijman et al. 2009). One of the initial scientific efforts for conservation and preservation programs of White-rumped Shama is through this population studies conducted by research team. By analyzing ex-situ populations of White-rumped Shama among bird keepers in Bengkulu City, those data can fit up the scientific information regarding this species. Clear number of both in situ and ex-situ birds can be assured the data will be useful for conservation programs in taking steps to preserve White-rumped Shama in their ex-situ and in situ habitat. Purpose of this research was to estimate the population of White-rumped Shama which are kept by Bengkulu's bird fanciers, analyze its population density, population distribution, and the profile of its keepers.

\section{MATERIALS AND METHODS}

\section{Study area}

This most recent study of White-rumped Shama has been conducted approximately for 3 months (June to September 2019), and covering all of 9 sub-districts located administratively in Bengkulu City, Bengkulu Province Indonesia. Those 9 sub-districts were namely Gading Cempaka, Ratu Agung, Kampung Melayu, Muara Bangkahulu, Ratu Samban, Selebar, Singaran Pati, Teluk Segara, and Sungai Serut (Figure 2). The research was assisted by 7 enumerators who were equipped with questionnaires and appropriately well trained on questionnaires prior they began the field study.

Bengkulu City is the capital of Bengkulu Province based on its geographical location is positioned on the west coast of Sumatra island (long $102^{\circ} 12^{\prime}$ to $102^{\circ} 22^{\prime \prime} \mathrm{E}$ and lat $3^{\circ} 45^{\prime \prime}$ to $\left.3^{\circ} 59^{\prime \prime} \mathrm{S}\right)$. Total area of Bengkulu City is 151.70 $\mathrm{km}^{2}$. According to Republic of Indonesia Government Regulation number 46/1986, administratively Bengkulu City borders are Bengkulu Utara District (north), Seluma District (south), Indian Ocean (west) and Bengkulu Tengah District (east) (Figure 2).

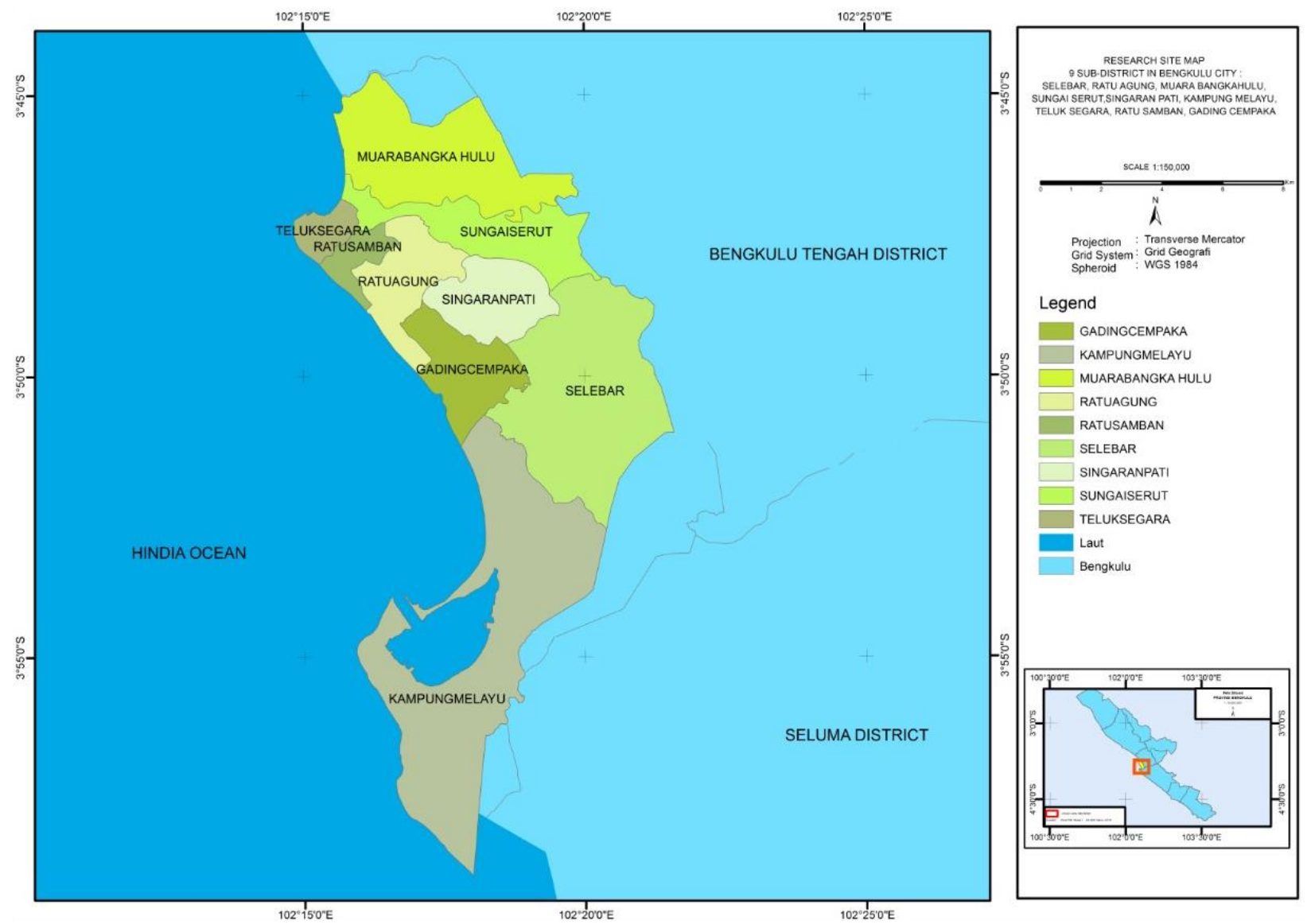

Figure 2. Location of 9 sub-districts in Bengkulu City, Indonesia as research site (long $102^{\circ} 12^{\prime}$ to $102^{\circ} 22^{\prime \prime} \mathrm{E}$ and lat $3^{\circ} 45^{\prime \prime}$ to $3^{\circ} 59^{\prime \prime} \mathrm{S}$ ). 


\section{Procedures}

Field observation method was conducted by doing a deep interview with White-rumped Shama bird keepers. The research site was determined purposively in Bengkulu City. Putranto et al. (2019) and Brata et al. (2019) reported that bird keepers in Bengkulu City have been choosing White-rumped Shama since last 5 years, well known as murai batu bird, and they found a serial specific daily management for this species such as frequency and duration for sunbathing, showering, feeding, drinking and so on. In this study, respondents were determined using the purposive sampling method and next respondents continued by a snowball sampling method. Characteristic parameters or profiles of bird fanciers recorded in this study were identification of name, sex, address and type of fancier. Total ex-situ population of White-rumped Shama was enumerated based on on-site number when the interviewing conducted, and number was divided by sexes. For total population of bird keepers in Bengkulu City, data obtained from number of respondents interviewed in this study and divided into two groups which are bird hobbyists or captive breeders.

\section{Data analysis}

Bird population data were analyzed by using population density formula and population distribution formula (Putranto et al. 2017), while profile of keepers was analyzed descriptively.

The formula for population density as follows (Rusdi et al. 2018; Azmi et al. 2017; Fairuztania dan Mustari 2017; Susiana et al. 2014: Fitri et al. 2013; Bismark 2011):

$$
\mathrm{D}=\frac{\mathrm{N}}{\mathrm{A}}
$$

Where:

D: density

$\mathrm{N}$ : number of White-rumped Shama bird

A: total area of research site

The formula for population distribution as follows (Putranto et al. 2017):

$$
\operatorname{VMR}=\frac{\boldsymbol{\delta}^{2}}{\mu}
$$

$$
\begin{aligned}
& \text { Where: } \\
& \text { VMR: Variance - Mean Ratio } \\
& \delta^{\mathbf{2}} \quad: \text { sample of variance } \\
& \boldsymbol{\mu} \quad: \text { total area of research site }
\end{aligned}
$$

\section{RESULTS AND DISCUSSION}

Following table and figures will show us about research data on total population on White-rumped Shama birds, birds population density and population distribution, and bird keepers in 9 pointed sub-districts of research sites in Bengkulu City.

\section{Total population of Copsychus malabaricus and birds keepers in Bengkulu City}

Table 1 is shown us about data of total population of ex-situ White-rumped Shama and total population of bird keepers who kept White-rumped Shama when the interviews were conducted in 9 sub-districts in Bengkulu City. We found that 642 White-rumped Shama birds were recorded and based on sexes they were structured into 434 male birds and 208 female birds (Figure 3). About 230 birds (148 males and 82 males) or approximately $35.8 \%$ of population was found in Teluk Segara and only 7 male birds $(1.1 \%)$ were found in Kampung Melayu. The sex ratio of male-female White-rumped Shama was approximately $2: 1$.

Researchers found 79 bird keepers divided into 78 male keepers $(98.7 \%)$ and only 1 female keeper (1.3\%) who kept White-rumped Shama when the interviews were conducted in 9 sub-districts in Bengkulu City. Muara Bangkahulu had approximately $21.5 \%$ of total keepers (17 males) and $5.1 \%$ (4 males) was found in other two sub-districts of Kampung Melayu and Gading Cempaka, respectively (Figure 4). Furthermore, we found that there are two categories of White-rumped Shama bird keepers type in Bengkulu City, bird hobbyists and captive breeders.

In this paper, a bird hobbyist is defined as an individual or a group of people who like White-rumped Shama birds for some specific reasons and widely known deliberately nurture a certain number of White-rumped Shama birds for the purpose of pleasure or hobbies. Captive breeder is defined as individuals or groups of people who like Whiterumped Shama bird for some specific reasons and widely known deliberately nurture a certain number of Whiterumped Shama birds for the purpose of conservation or economic reasons which is to get a financial benefit from trading White-rumped Shama birds produced by a captive breeding farm. In this study, captive breeding is also purposed for an economic benefit. Captive breeders will receive money from illegal trading activities they made. There were about 68 bird hobbyists $(86.1 \%)$ and 11 captive breeders (13.9\%, Figure 5) in Bengkulu City.

\section{White-rumped Shama population density and population distribution}

Based on a formula of population density, the population density of White-rumped Shama in 9 subdistricts in Bengkulu City was 4.23 birds per $\mathrm{km}^{2}$. Based on sexes, we found that its population densities were 2.86 male birds per $\mathrm{km}^{2}$ and 1.37 female bird per $\mathrm{km}^{2}$. The population distribution of White-rumped Shama in 9 subdistricts in Bengkulu City was 4.8 (VMR > 1.0), and interpreted as negative binomial distribution or overdispersed (cluster distribution population). Figure 6 shown population density and population distribution of Whiterumped Shama in 9 sub-districts in Bengkulu City. 
Table 1. Total population of ex-situ White-rumped Shama kept by keepers and total population of bird keepers in 9 sub-districts in Bengkulu City, Indonesia

\begin{tabular}{|c|c|c|c|c|c|c|}
\hline \multirow{2}{*}{ Sub-districts } & \multicolumn{2}{|c|}{ Number of bird } & \multicolumn{2}{|c|}{ Number of keepers } & \multicolumn{2}{|c|}{ Type of keepers } \\
\hline & Male & Female & Male & Female & Bird hobbyist & Captive breeders \\
\hline Muara Bangkahulu & 72 & 7 & 17 & 0 & 16 & 1 \\
\hline Sungai Serut & 21 & 7 & 13 & 0 & 13 & 0 \\
\hline Singaran Pati & 30 & 0 & 11 & 0 & 11 & 0 \\
\hline Selebar & 51 & 31 & 9 & 1 & 6 & 4 \\
\hline Kampung Melayu & 7 & 0 & 4 & 0 & 4 & 0 \\
\hline Teluk Segara & 148 & 82 & 5 & 0 & 3 & 2 \\
\hline Ratu Samban & 40 & 23 & 7 & 0 & 6 & 1 \\
\hline Gading Cempaka & 33 & 34 & 4 & 0 & 3 & 1 \\
\hline Ratu Agung & 32 & 24 & 8 & 0 & 6 & 2 \\
\hline Sub Total & 434 & 208 & 78 & 1 & 68 & 11 \\
\hline Total & \multicolumn{2}{|c|}{642} & \multicolumn{2}{|c|}{79} & \multicolumn{2}{|c|}{79} \\
\hline
\end{tabular}

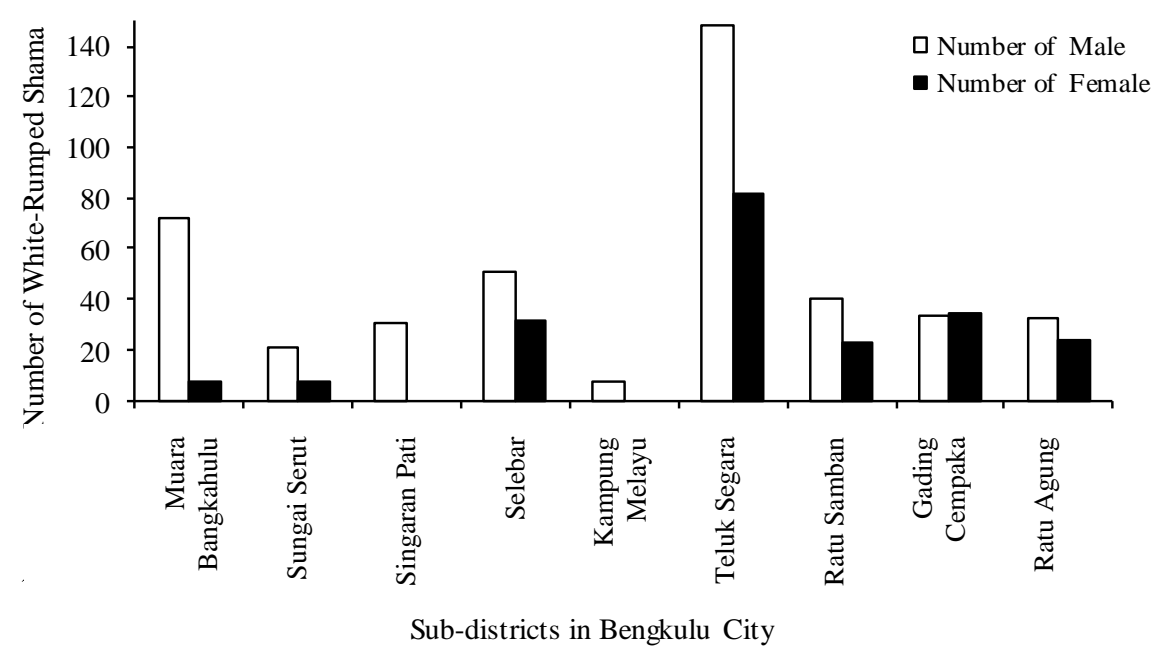

Figure 3. Population of White-rumped Shama kept by bird keepers in 9 sub-districts of Bengkulu City, Indonesia

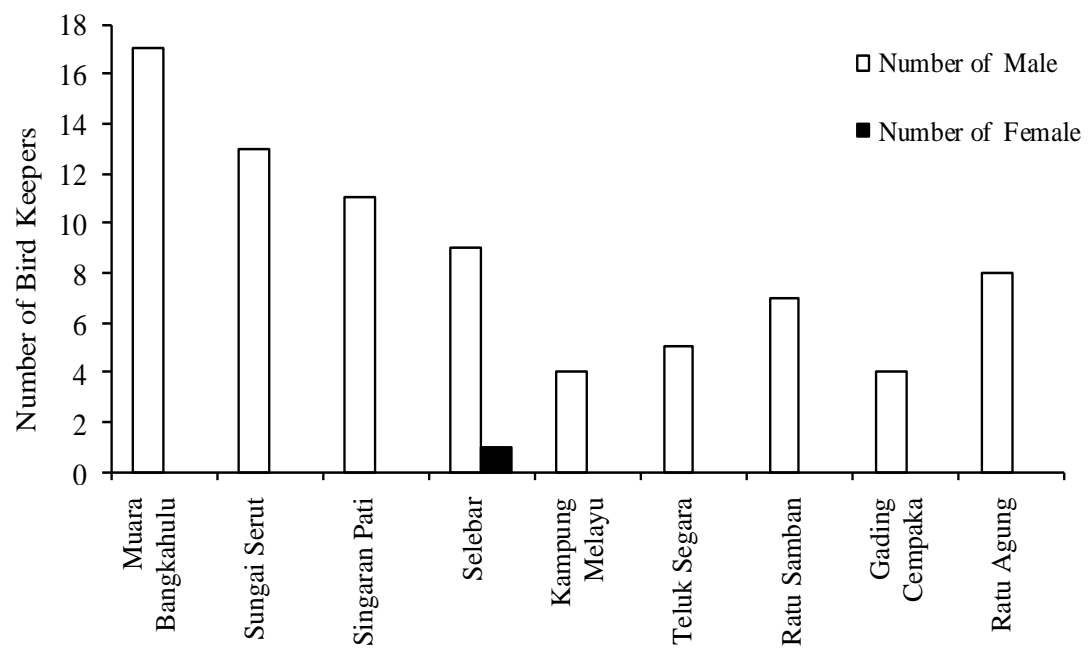

Sub-districts in Bengkulu City

Figure 4. Population of White-rumped Shama bird keepers in 9 sub-districts of Bengkulu City, Indonesia 


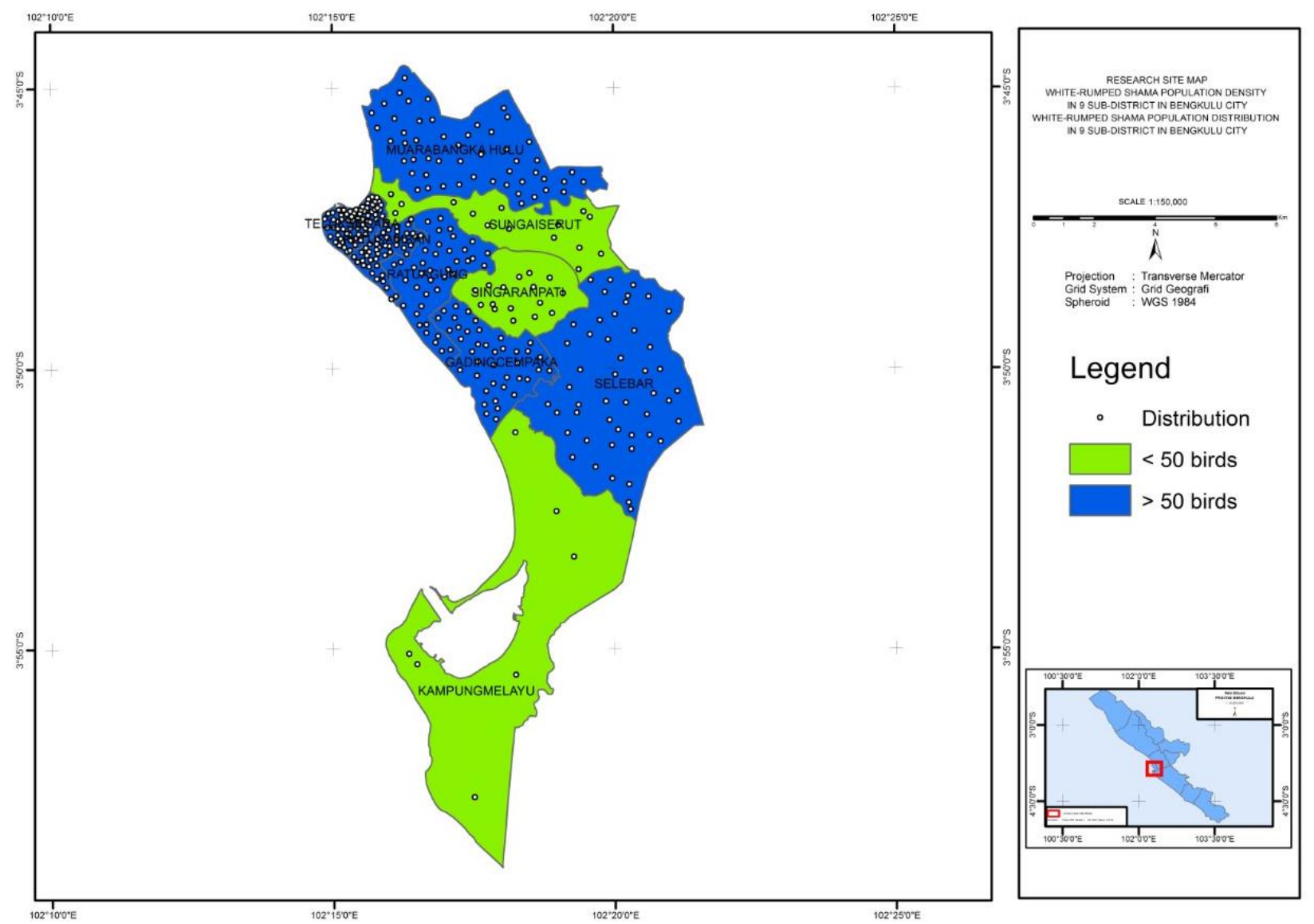

Figure 6. Population density and population distribution of White-rumped Shama in 9 sub-districts in Bengkulu City, Indonesia

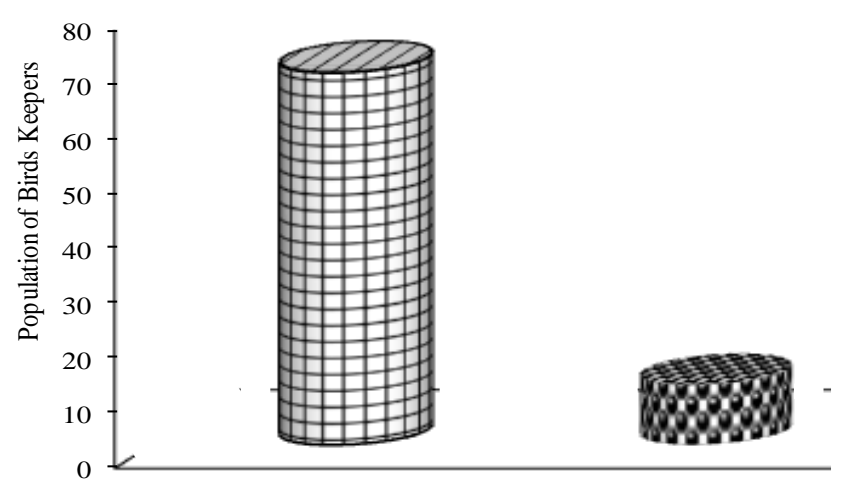

Figure 5. Population of White-rumped Shama bird keepers type: bird hobbyists (left) and captive breeders (right)

\section{Discussion}

The most recent results of scientific studies on Whiterumped Shama birds are still very limited in terms of quantity of articles (Putranto et al. 2018). As the first report on ex situ population of White-rumped Shama kept by bird keepers, this paper is being expected to be able to become one of qualified references and sources of scientific information about this species for birdkeepers, breeders, biologist and conservationist in Indonesia and other countries. Researchers believe this fundamental information can enriched scientific data to intensify development of conservation programs of Indonesian endemic birds in the future.

Researchers of Faculty of Agriculture, Universitas Bengkulu, Indonesia have been working on White-rumped Shama bird or also well known in their local name as murai batu bird since 3 years ago. It is proven by a serial scientific publication by Putranto et al. (2018) who reported about White-rumped Shama reproduction status in their captive breeders environment in Bengkulu City, then reports on population of White-rumped Shama bird lovers in Bengkulu City (Putranto et al. 2019), and another report on its daily management description (Brata et al. 2019).

The data on Table 1 shows that more than 600 Whiterumped Shama birds were enumerated in their ex-situ habitat covering 9 sub-districts in Bengkulu City. As mentioned by Saputro et al. (2016) earlier, this species is well known as a bird which relatively not easily stressed as long as adequate care is given. We assumed this status was found in their in-situ habitat. Because in contrary among Bengkulu's bird keepers, locally this bird is also widely known as a stressful bird based on its high mortality rate when they have to adjust themself into a new ex-situ environment or treatment by keepers. For example, a new changing feed from raw feed such as kroto (ant eggs) or crickets into a commercial feed, a new cage body or new cage facilities, or a new face of new fancier can be a 
stressor which leads to a mortality of this bird species. When demand of this bird increase and the available number of birds in captive breeders are not enough, probably the birds captured from in situ habitats to fulfill its potential demand of White-rumped Shama as a pet and circulate in bird market can be larger in number. It is common for researchers to believe capturing animals, in this case, White-rumped Shama, from its in situ habitat when it is not accompanied by an appropriate surveillance and preservation program, it can contribute for a population decline and scarcity in nature.

Male White-rumped Shama become the main choice of bird keepers in Bengkulu City than female White-rumped Shama birds. This situation can be seen from the rate of sex ratio of male-female birds kept which average at 2: 1 . By this sex ratio, we can also interpret that among bird keepers in Bengkulu City if there are 2 male birds that are kept then we can find 1 female that is maintained. Putranto et al. (2017) found a similar pattern among burgo fanciers in Bengkulu who prefer to have male rather than female chicken. In case of White-rumped Shama birds, less number of female birds are kept in Bengkulu City caused by reason of male bird has a beautiful chirping and more expensive than female birds. For some Indonesians, it is more prestigious to keep male rather than female Whiterumped Shama. It is also recorded by Brata et al. (2019), for local bird keeper's in Bengkulu City (both hobbyists and breeders) their reason to keep female birds because they would like to create matchmaking between a mature male White-rumped Shama with a mature female. Matchmaking process is the first activity required to be conducted by keepers and aimed to make a male and a female bird feel comfortable and paired. This reproduction technique will continue by some sexual breeding activities by pair. Putranto et al. (2018) reported that a process of matchmaking between male and female White-rumped Shama is begun by placed a pair of bird in a closed cage or in two side by side closed cages in order to make them know each other. If those two birds are attracted to each other then they will be showing a receptiveness which is marked by the two birds always close together and respond to each other by chirping. The matchmaking process can take place in quite long time between 2-3 weeks or even months.

Figure 6 is shown population density of this species. Population density rate is obtained by dividing number of individuals found in observation area with total area of research site (Fairuztania and Mustari 2017). Furthermore, the population density of White-rumped Shama in 9 subdistricts in Bengkulu City based on sex (male and female) rate was approximately 2 and 1 birds per $\mathrm{km}^{2}$, respectively approximately. This density number is similar to sex ratio data which we assume that in every $1 \mathrm{~km}^{2}$ of Bengkulu City area if there are 2 male birds that are kept in then we can find 1 female that is maintained.

This research team published a paper on endemic chicken population in Bengkulu coastal area (Putranto et al. 2017). Furthermore, we applied a combination of population census methods by using regular census questionnaires and digital technology applications. The combination technique can be improved for further developed real-time data. Researcher assumes that this research results (population density and distribution) can enrich the existing scientific data which can be used by local government of Bengkulu to design a development program, especially for a flora and fauna conservation. Suggested by past researchers, local government as local authority and decision-maker should further develop a conservation initiation supported by innovative approaches from experts (Kuswanda and Mukhtar 2010). However in fact, Susatya (2003) wrote that most conservation programs had no comprehensive and significantly clear management regarding conservation of flora and fauna in Bengkulu.

Based on Variance - Mean Ratio (VMR) formula, we found that White-rumped Shama population distribution in Bengkulu City was $>1.0$ (Figure 5). It can be interpreted as negative binomial distribution or over-dispersed or cluster distribution population (Putranto et al. 2017). According to Ruetz III et al. (2005), the population distribution can be defined as movement of individuals into or out of the population. In White-rumped Shama case, the movement into or out of the population will be fully managed by bird keepers. Furthermore, a past study by Ruetz III et al. (2005) explained that population distribution is of importance of spread flora, fauna or other creatures such as humans geographically from former habitat to another new habitat prior to inhabitation. Ruetz III et al. (2005) added that in contrary to ex-situ, in situ population distribution happens due to the stimulation of some conditions such as searching for feeding resources, water, and wind direction, characteristic of climatology, sexual behaviors, and other internal and external factors.

Based on data in Figure 4 we found that majority of White-rumped Shama bird keepers in Bengkulu City were male keepers. Among 9 sub-districts in Bengkulu as research sites, Muara Bangkahulu sub-district has a highest number of White-rumped Shama bird keepers (more than $20 \%$ of total keepers), followed by other two sub-districts of Kampung Melayu and Gading Cempaka as the lowest number of White-rumped Shama bird keepers approximately 5\%, respectively (Figure 3). A similar pattern also reported by a previous study by Irawati et al. (2016) which stated that majority (more than 70\%) of Nuri Talaut bird keepers in Karakelang island was male keepers. Putranto et al. (2010, 2017) also found a similar situation regarding Burgo keepers in Bengkulu which was more male keepers than female keepers. We assume that birdrearing activities are part of a man's hobby among bird keepers in Bengkulu City. The role of methods of snowball sampling in the shaping of almost exclusively male group of respondents was also estimated to become the main reason for only 1 female bird keepers was recorded in Bengkulu City. In this study, we also found average age of White-rumped Shama bird keepers in Bengkulu City was 37.14 years (Putranto et al. 2019). Yustianti (2019) reported that majority or more than $90 \%$ of bird keepers age in Indonesia was ranged between 15 to 65 years old. It means the average age of White-rumped Shama keepers in Bengkulu City is still in same range as Yustianti (2019) report. 


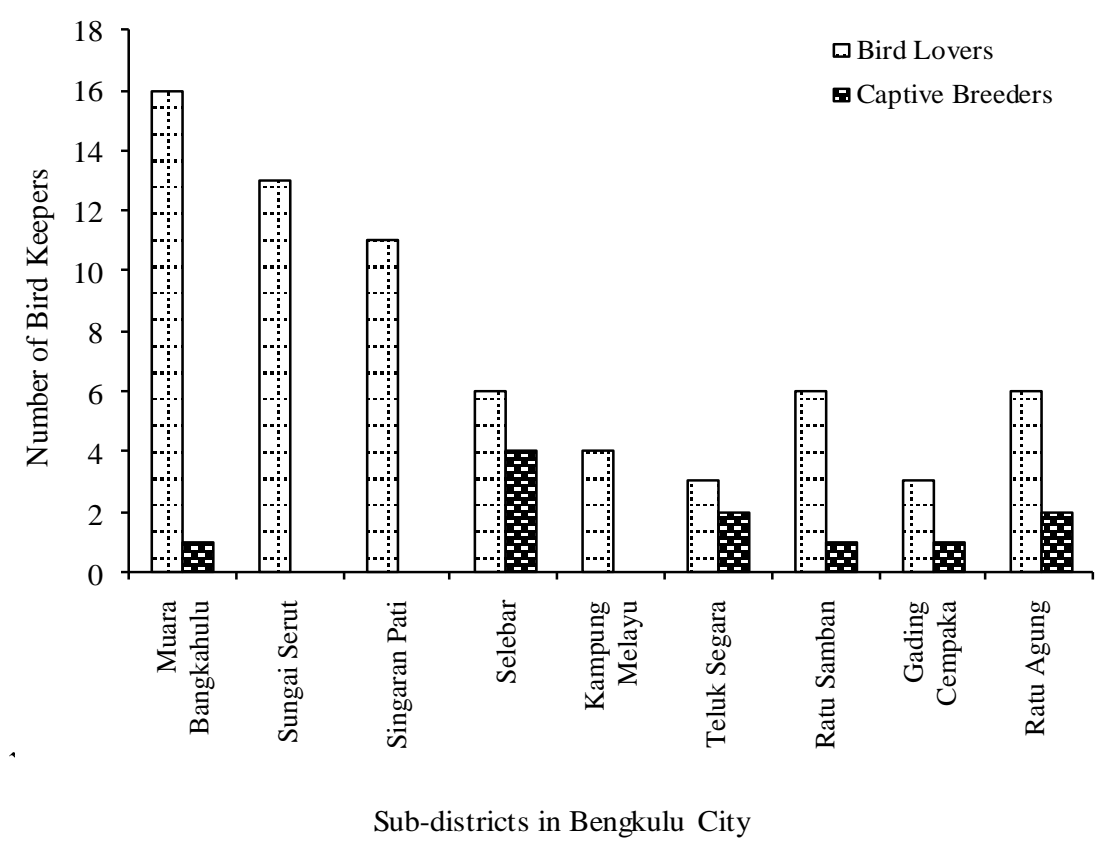

Figure 7. Population of White-rumped Shama bird hobbyists and captive breeders in 9 sub-districts of Bengkulu City, Indonesia

In the year of 2019 , there were about 68 bird hobbyists $(86.1 \%)$ and 11 captive breeders (13.9\%, Figure 7). This number is smaller than research result by a previous study by Sujana (2016). Data provided by Sujana (2016) shown that nationally there were about 70,000 White-rumped Shama bird keepers registered and about 6,200 of them are lived in Bandung city of West Java Province. Whiterumped Shama bird keepers in Bengkulu City can be found widely distributed in all sub-district area (Figure 6). Average population for bird keepers was approximately 7 bird lovers per sub-district, with most populated subdistrict was Muara Bangkahulu (16 bird keepers or approximately $23 \%$ of total bird keepers population). The smallest population of bird keepers was recorded at Teluk Segara sub-district and Gading Cempaka sub-district which are 3 bird keepers or approximately only $4 \%$ of total bird keepers population, respectively.

While captive breeders of White-rumped Shama birds in Bengkulu City receive financial benefit from trading White-rumped Shama birds produced by a captive breeding farm. Most populated captive breeders were found in Selebar sub-district by a number of 4 captive breeders or approximately $36 \%$ of total captive breeders population. Researcher only found White-rumped Shama captive breeders on 6 sub-districts out of total 9 sub-districts in Bengkulu City which was designated as research sites. Then, in another 3 sub-districts (Sungai Serut, Singaran Pati, and Kampung Melayu) we found no White-rumped Shama bird, captive breeders. Leus (2011) reported that captive breeding is a program that becomes one of conservationist tools to prevent the extinction status of a species, subspecies or population. As captive breeders, they should be registered as legal breeders by a national or local authority and receive a legal certificate which mentions their name and address. However, researchers found that only 2 out of 11 captive breeders (18\%) who can show the certificate to enumerators when interviewing conducted. Unregistered captive breeders are a sign of a dysfunctional and potentially harmful captive breeding. This situation must be corrected by the local authority so that actions to protect White-rumped Shama populations, its migration and trade, and efforts to regulate the origin of birds kept can be legally documented in the future

Harris et al. $(2015,2017)$ initiated a model as a viable conservation solution for bird conservation. However, the proposed model has mentioned earlier is still cannot be applied in Indonesia. In this study result, we found more than $80 \%$ of local captive breeder of White-rumped Shama bird in Bengkulu City is unregistered by the authority. Researchers are still cannot uncover some basic questions regarding conservation programs such as the origin of White-rumped Shama which kept by captive breeder, the number of birds has been traded or to whom they sold the birds. There was no recorded data nor those unregistered captive breeders did not give any clear answers.

Among international conservationists, it is strongly believed that captive breeding program is directed only as a business opportunity prefer than as a potential conservation solution mainly on a potential negative side of a supplyside conservation strategy. They still have not recommended any economical oriented captive breeding program. However based on population data of existing local bird hobbyists and captive breeders in Bengkulu City, it seems that business of animals has still become a 
potential and profitable for them. This situation is as if justify a previous report. According to Sujana (2016), in Indonesia nowadays flora and fauna business sector becomes potential and prospective option for businessman to carry out their business activities, and White-rumped Shama captive breeding program is recorded as one of it. A large number of White-rumped Shama bird keepers is also to create a promising market for entrepreneurs to initiate a captive breeding program of White-rumped Shama. In addition, Sujana (2016) stated that in fact the near extinction status of White-rumped Shama bird in its in situ habitat due to illegal poaching and illegal trading, an issued regulation and law by Indonesia authority to utilize only a captive breeding birds for a bird contest would develop a strong reason for some local bird breeders in Indonesia, especially in Bengkulu City to conduct this captive breeding business.

Researchers strongly believe that efforts to strengthen a conservation program such as registered and controlled captive breeding programs of White-rumped Shama bird in Bengkulu City should be intensified and given more serious attention by societies and authorities. Local authority in Bengkulu City should bring order to this situation. This is intended in order to all demands of birdloving communities who would like to keep white-rumed shama birds as pets, traded or joined a bird-singing contest not only rely on birds from wild-caught but can also be met from birds bred by registered captive breeding farm. When those demands can be fully supplied by a registered and controlled captive breeders, it can reliably decrease the possibility of wild-caught. If these ideal conditions equipped by a well-maintained environment exist, a highly possibility of sufficient in situ wildlife population would be created.

\section{ACKNOWLEDGEMENTS}

This research is part of Hibah Kompetitif Penelitian Nasional Skim Penelitian Dasar which is fully funded by DRPM the Ministry of Research, Technology and Higher Education Republic of Indonesia by contract number 774/UN30.1/LT/2019 dated on 15 March 2019. The research team would like to thank the DRPM the Ministry of Research, Technology and Higher Education Republic of Indonesia, LPPM Universitas Bengkulu, Department of Animal Science Faculty of Agriculture Universitas Bengkulu, White-rumped Shama keepers in Bengkulu City (bird lovers and breeders), members of the research group and enumerators in the field.

\section{REFERENCES}

Alves RRN, Lima JRF, Araujo HFP. 2013. The live bird trade in Brazil and its conservation implications: an overview. Bird Conservation International 23: 53-65.

Amama F, Triwiduri R. 2007. Responsibility of rearing birds http://www.burung.org/ com_content\&view=article\&id=68: memelihara-burung=yangbertanggungjawab\&catid $=28$ :article $\&$ itemid=75. [Indonesian]
Azmi L, Sarong MA, Kamal S. 2017. Population density and habitat preferences of shingle urchin (Colobocentrotus atratus) in Rieting beach Leupung sub-district, district of Aceh Besar. Jurnal Ilmiah Mahasiswa Fakultas Keguruan dan Ilmu Pendidikan Unsyiah 2 (1): 16. [Indonesian]

BirdLife International. 2015. Species factsheet: Copsychus malabaricus. BirdLife International, Cambridge, UK.

Brata B, Putranto HD, Yumiati Y. 2019. Description of potential animal management of burung murai batu: a case study in Bengkulu City. Proceeding of BKS PTN Wilayah Barat National Seminar, Faculty of Agriculture Jambi University, 28-29 August 2019. [Indonesian]

Bismark, M. 2011. Standard Operating Procedures (SOP) For Species Diversity Surveys in Conservation Areas. Ministry of Forestry and ITTO, Bogor.

CABI.org. 2020. Invasive species compendium detailed coverage of invasive species threatening livelihoods and the environment worldwide. https://www.cabi.org/isc/datasheet/88140.

Collar NJ. 2005. Family Turdidae (Thrushes). In: Del Hoyo J, Elliott A, Christie DA (eds.). Handbook of the Birds of the World. Vol 10: Cuckoo-shrikes to Thrushes. Lynx Edicions, Barcelona, Spain.

Duckworth JW, Batters G, Belant JL, Bennett EL, Brunner J, Burton J, Challender DWS, Cowling V, Duplaix N, Harris JD, Hedges S, Long B, Mahood S P, McGowan P JK, McShea W J, Oliver WLR, Perkin S, Rawson BM, Shepherd CR, Stuart SN, Talukdar BK, van Dijk PP, Vié JC, Walston JL, Whitten T, Wirth R. 2012. Why South-East Asia should be the world's priority for averting imminent species extinctions, and a call to join a developing cross-institutional programme to tackle this urgent issue. Sapiens 5 (2): 77-95.

Eaton JA, Shepherd CR, Rheindt FE, Harris JBC, van Balen SB, Wilcove DS, Collar NJ. 2015. Trade-driven extinctions and near-extinctions of avian taxa in Sundaic Indonesia. Forktail 31: 1-12.

Fahruzi A, Suryowinoto A. 2019. Implementation of PID control in White-rumped Shama egg incubators. Inform Jurnal Ilmiah Bidang Teknologi Informasi dan Komunikasi 4 (1): 1-7. [Indonesian]

Fairuztania ZZ, Mustari AH. 2017. Habitat characteristics and population of booted macaque (Macaca ochreata) in Tanjung Peropa wildlife reserve, Southeast Sulawesi. Jurnal Wasian 4 (2): 97-108. [Indonesian]

Fan MW, Lin RS, Fang W, Lin YH. 2009. The distribution and abundance of the alien invasive White-rumped Shama (Copsychus malabaricus) in Taiwan. Taiwania 54 (3): 248-254.

Fitri R, Rizaldi, Novarino W. 2013. Population density, group structure and diet of mitered leaf-monkey (Presbytis melalophos) at the Biological Research and Educational Forest of Andalas University. Jurnal Biologi Universitas Andalas 2 (1): 25-30. [Indonesian]

Harris JBC, Tingley MW, Hua F, Yong DL, Adeney JM, Lee TM, Marthy W, Prawiradilaga DM, Sekercioglu CH, Winarni N. 2017. Measuring the impact of the pet trade on Indonesian birds. Conserv Biol 31: 394-405.

Harris JBC, Green JMH, Prawiradilaga DM, Giam X, Giyanto, Hikmatullah D, Putra CA, Wilcove DS. 2015. Using market data and expert opinion to identify overexploited species in the wild bird trade. Biological Conservation 187: 51-60.

Iqbal M, Ajiman, Richard A, Noske, Setiawan D. Hunting of a very large aggregation of eyebrowed thrushes Turdus obscurus in Sumatra. Kukila 17 (2): 68-71.

Irawati D, Arini D, Yuliantoro I. 2016. The typology and motivation of owner community of Nuri Talaud as protected bird in Karakelang island. Jurnal Penelitian Sosial dan Ekonomi Kehutanan 13 (1): 3746. [Indonesian]

Iskandar J. 2016. A dilemma between hobby, bird trade and bird conservation. Chimica et Natura Acta 2 (3):180-185. [Indonesian]

Jepson P. 2010. Towards and Indonesian Bird Conservation Ethos: Reflections from a Study of Bird-keeping in the Cities of Java and Bali. In: Tidemann S, Gosler A (eds.). Ethnoornithology: Birds, Indigenous Peoples, Culture and Society. Earthscan, London.

Kuswanda W, Mukhtar AS. 2010. Management of population terrestrial big mammals in Batang Gadis national park, North Sumatra. Jurnal Penelitian Hutan dan Konservasi Alam 7 (1): 59-74. [Indonesian]

Leus K. 2011. Captive breeding and conservation. Zoology in the Middle East 54 (sup3): 151-158.

Lee JGH, Chng SCL, Eaton JA. 2016. Conservation strategy for Southeast Asian Songbirds in trade: recommendations from the first Asian Songbird Trade Crisis Summit 2015 held in Jurong Bird Park, 
Singapore, 27-29 September 2015. Wildlife Reserves Singapore, Singapore; TRAFFIC Southeast Asia, Selangor, Malaysia.

Low E. 2006. White-rumped Shama. In: Singapore Infopedia: an electronic encyclopedia on Singapore's history, culture, people and events. Singapore: National Library Board http://eresources.nlb.gov.sg/infopedia/articles/SIP_1510_2009-0421.html.

Mua'rif Z. 2012. Secrets of Captive Management of White Rumped Shama. Lyli Publisher, Yogyakarta. [Indonesian]

Nijman V. 2010. An overview of international wildlife trade from Southeast Asia. Biodiversity and Conservation 19: 1101-1114.

Nijman V, Shepherd CR, van Balen SB. 2009. Declaration of the Javan hawk-eagle Spizaetus bartelsi as Indonesia's national rare animal impedes conservation of the species. Oryx 43: 122-128.

Putranto HD, Santoso U, Warnoto. 2010. A study on population density and distribution pattern of domesticated Bengkulu native burgo chicken. Media Kedokteran Hewan 26 (2): 198-204. [Indonesian]

Putranto HD, Hasibuah GP, Yumiati Y, Setianto J, Brata B, Kurniati N, Hakiki FF. 2017. The estimation of dynamical distribution of domesticated Burgo chicken population in Bengkulu coastal area, Indonesia. Biodiversitas 18 (2): 458-464.

Putranto HD, Okvianto D, Prakoso H. 2018. Reproductive studies on murai batu (Copsychus malabaricus) in Bengkulu local captive breeding. Jurnal Sain Peternakan Indonesia 13 (2): 130-139. [Indonesian]

Putranto HD, Brata B, Yumiati Y. 2019. Profile and population of mura batu fanciers in Bengkulu City. Proceeding of BKS PTN Wilayah Barat National Seminar, Faculty of Agriculture Jambi University, 2829 August 2019: 1225-1234. [Indonesian]

Pyle RL, Pyle P. 2009. The Birds of the Hawaiian Islands: Occurrence, History, Distribution, and Status (Version 1). Bishop Museum, Honolulu, Hawaii, USA.

Ruetz III CR, Trexler JC, Jordan F. 2005. Population dynamics of wetland fishes: spatio-temporal patterns synchronized by hydrological disturbance. J Anim Ecol 74: 322-332.
Rusdi M, Muttaqin T, Aryanti NA. 2018. Population estimation and characteristics of lutung Jawa (Trachypithecus auratus e. Geoffroy Saint-Hilaire, 1812) in Bandealit resort Meru Betiri national park. Journal of Forest Science Avicennia 1 (1): 1-13. [Indonesian]

Rosyadi I, Tetuka B, Embeua E, Mukaram E, Barakai N, Djorebe R. 2015. Parrot bird-keeping in North Maluku. Acta Veterinaria Indonesiana 3 (2): 51-57. [Indonesian]

Saputro AD, Nova K, Kurtini T. 2016. The behaviours of White-rumped Shama (Copsychus malabaricus) ready to production. Jurnal Ilmiah Peternakan Terpadu 4 (3): 188-194. [Indonesian]

Susatya A. 2003. The population and life history of rare species of Rhizantes loweii (BECC), harms at Katenong Kerinci-Seblat National Park. Jurnal Ilmu-ilmu Pertanian Indonesia 5 (2): 71-76. [Indonesian]

Susiana, Ningsih A, Amran MA. 2014. The abundance and density of kima (Tridacnidae) in Spermonde islands. Jurnal Ilmiah Agribisnis dan Perikanan 6 (3): 55-64. [Indonesian]

Sujana FH. 2016. Analysis of business feasibility study of breeding White-rumped Shama birds (a survey on White-rumped Shama bird breeder in Bandung). The VI Entrepreneurship and Business Innovation National Seminar, Widyatama University Bandung Indonesia, 2016. [Indonesian]

Shepherd CR, Shepherd LA, Foley KE. 2013. Straw-headed bulbul Pycnonotus zeylanicus: legal protection and enforcement action in Malaysia. BirdingASIA 19: 92-94.

Shepherd CR, Sukumaran J, Wich SA. 2004. Open season: an analysis of the pet trade in Medan, Sumatra 1997-2001. Selangor, Malaysia: TRAFFIC Southeast Asia 59.

van Balen SB, Eaton JA, Rheindt FE. 2013. Biology, taxonomy and conservation status of the short-tailed green magpie Cissa [t.] thalassina from Java. Bird Conservation International 22: 91-109.

Yustianti V. 2019. Bird keepers social-economic background and motivation between township and rural area in Surabaya City. Universitas Negeri Surabaya, Surabaya. [Indonesian] 